\title{
Forum: Solidarity
}

\author{
Lesley Gill · Sharryn Kasmir
}

The concept of solidarity developed in 19th century Europe as workers confronted the social fragmentation generated by capitalism, and it became central to the development of Proudhonian socialism, the Chartist movement, and the First International. The word is used in the documents of these movements to imagine and name a decidedly modern subjectivity for workers, and it references a set of social relations that extend beyond kinship, tradition, or village. Further, the concept of solidarity is more than descriptive; it involves a politics of recognition and requires organizing. In the twentieth century, W. E. B. Du Bois famously promoted the solidarity of African and Asian peoples as a necessary response to the global system of exploitation; Che Guevara remade the figure of the revolutionary as one whose very personhood was created through solidarity; and post-colonial activists/ theorists such as Franz Fanon warned that all calls to solidarity simultaneously imply exclusion.

In this forum, we ask contributors to explore the history of solidarity, as well as its contemporary meanings and practices. We are interested in how the concept has been used and reworked over time and space. Solidarity has always involved international alliances, but nowadays the pressures toward social fragmentation are particularly intense. We therefore pay special attention to the emergence of global networks and relationships that seek to build alliances and create solidarity in new ways.

L. Gill $(\bowtie)$

Vanderbilt University, Nashville, TN, USA

e-mail: lesleygill@optonline.net

S. Kasmir

Hofstra University, Hempstead, NY, USA 